JKKP: Jurnal Kesejahteraan Keluarga dan Pendidikan

http://doi.org/10.21009/JKKP

DOI: doi.org/10.21009/JKKP.032.02

E-ISSN: 2597-4521

\title{
Hubungan Antara Coping Dengan Kualitas Perkawinan Pada Ibu Rumah Tangga
}

\author{
Ayu Annisa Sutarjo 1,a), Uswatun Hasanah ${ }^{1, b)}$, Guspri Devi Artanti $\left.2, \mathrm{c}\right)$ \\ a)annisaa72@yahoo.com , b) us nina@yahoo.com \\ 1)P rogram Studi Pendidikan Kesejahteraan Keluarga \\ 2)P rogram Studi Pendidikan Tata Boga \\ Fakultas Teknik, Unversitas Negeri J akarta \\ J In. Rawamangun Muka, J akarta Timur. 13220
}

\begin{abstract}
Abstrak
Ketika suatu perkawinan sering diwarnai pertengkaran, merasa tidak bahagia, atau masalah lainnya sering kali terpikir untuk segera mengakhiri pernikahan tersebut. Berdasarkan data di Pengadilan Agama Kota Bekasi, tahun 2012 jumlah perkara cerai sebanyak 1.716, tahun 2013 perkara cerai sebanyak 1.750 dan tahun 2014 menjadi 1.825 perkara cerai. Faktor jenis perkara cerai terbanyak setiap tahunnya disebabkan ketidak harmonisan $30 \%$, gangguan pihak ketiga $24 \%$, persoalan ekonomi $20 \%$. Kualitas dalam pernikahan bergantung pada kebahagiaan salah satu pasangan dengan hubungan mereka, sensitivitas mereka satu sama lain, validasi mereka terhadap perasaan satu sama lain, serta keterampilan komunikasi dan manajemen konflik mereka. Tujuan penelitian ini untuk menganalisis hubungan antara coping ibu dengan kualitas perkawinan. Penelitian ini dilaksanakan di Kota Bekasi. Metode penelitian yang digunakan adalah survei. Penelitian ini menggunakan metode penelitian kuantatif asosiatif. Populasi pada penelitian ini adalah ibu rumah tangga di Kota Bekasi, jumlah sampel yang digunakan sebanyak 80 orang. Teknik sampling yang digunakan multistage sampling. Hasil penelitian menunjukkan bahwa terdapat hubungan yang signifikan antara Coping dengan Kualitas Perkawinan dengan koefisien korelasi sebesar 0,351. Hasil uji signifikansi pada koefisiennya sebesar 3,320 dan dapat disimpulkan bahwa koefisien korelasi adalah signifikan. Koefisien determinasi yang diperoleh sebesar 12,3\%, menunjukan variabel Kualitas Perkawinan ditentukan oleh Coping. Persamaan regresi yang dihasilkan menunjukkan bahwa setiap peningkatan satu skor coping dapat menyebabkan peningkatan kualitas perkawinan ibu rumah tangga sebesar 0,39 pada konstanta 43,39. Hasil Uji Hipotesis menyatakan bahwa terdapat hubungan yang positif dan signifikan antara Coping dengan Kualitas Perkawinan pada Ibu rumah tangga di Kota Bekasi.
\end{abstract}

Kata Kunci: Coping, Kualitas Perkawinan, Ibu Rumah Tangga

\section{The Relationship Between Coping with Marital Quality of Housewifes}

\begin{abstract}
When a marriage is often colored by an argument, feeling unhappy, or other eating issues it will occur to immediately end the marriage. Based on data from the Religious Court of Bekasi, in 2012 the number of divorce cases as many as 1,716, in 2013 as many as 1,750 and divorce cases in 2014 to 1,825 divorce cases. Factors most types of divorce cases each year are caused disharmony $30 \%, 24 \%$ third-party interference, economic issues $20 \%$. The quality of marital happiness depends on one pair with their relationship, their sensitivity to one another, their validation to the feelings of each other, as well as communication skills and management of their conflicts. The purpose of this study to analyze the relationship between housewife coping with
\end{abstract}


marital quality. The research was conducted in Bekasi. The research method used was survey. This study used quantitative associative research methods. The population in this study was a housewife in Bekasi, the number of samples used as many as 80 people. The sampling technique used multistage sampling. The results showed that there was a significant relationship between Coping with Quality Marriage with a correlation coefficient of 0.351 . The results of significance test on coefficient is 3.320, and it can be concluded that the correlation coefficient is significant. The coefficient of determination obtained was $12.3 \%$, showing marital quality variables determined by coping. The result of regression equation showed that any increase in the score of coping can lead to improved quality of marriage housewife constant of 0.39 at 43.39 . Test Results hypothesis states that there is a positive and significant relationship between Coping with Quality Marriages on housewife in Bekasi.

Keywords: Coping, Quality of Marriage, Housewife

\section{PENDAHULUAN}

Ketika suatu perkawinan sering diwarnai pertengkaran, merasa tidak bahagia, atau masalah lainnya sering kali terpikir untuk segera mengakhiri pernikahan tersebut. Perceraian dapat diartikan sebagai suatu tindakan terakhir dari penyesuaian perkawinan yang buruk dan terjadi bila suami istri sudah tidak mampu lagi mencari cara untuk menyelesaikan masalah yang dapat memuaskan kedua belah pihak (Hurlock, 1997).

Sikap mudah marah dari pasangan, terjadinya kecurangan ataupun ketidaksetiaan, persoalan salah satu pasangan ataupun keduanya selalu berada di luar rumah sehingga tidak mempunyai waktu yang cukup untuk berinteraksi dengan keluarga sehingga menimbulkan konflik. Berdasarkan ciri pembawaan seorang individu maupun disebabkan oleh tingkah laku ataupun perbuatan dari masing-masing pasangannya dapat membentuk kemampuan pasangan suami istri mengatasi berbagai masalah dalam perkawinannya.

Menurut Bodenmann (1998) dalam Baron dan Byrne (2005) laki-laki lebih cenderung untuk menghindari berbicara mengenai konflik daripada perempuan, namun hal ini juga bukan solusi yang memuaskan. Ketika konflik dan ketidaksetujuan muncul dalam suatu hubungan, sering kali hal-hal ini berkembang menjadi suatu konteks dengan fokus interaksinya adalah mana yang benar dan mana yang salah atau mana yang menang dan mana yang kalah.

Perceraian merupakan fenomena puncak stres bagi istri. Menurut Lazarus (1966), bagaimana peristiwa kehidupan dinilai merupakan penentu penting apakah peristiwa tersebut menyebabkan stres (Lazarus, 1966). Relevan dengan perbedaan individual dalam merespon situasi penuh stres merupakan konsep coping, yaitu bagaimana orang berupaya mengatasi masalah atau menangani emosi yang umum negatif yang ditimbulkannya. Coping dapat difokuskan untuk menyelesaikan masalah atau untuk mengatur berbagai emosi yang ditimbulkan oleh masalah tersebut (Lazarus \& Folkman, 1966).

Orang secara sadar memilih strategi coping dengan dasar bagaimana mereka mempersepsikan dan menganalisis situasi. Coping terjadi ketika seseorang mempersepsikan suatu situasi membebani atau melampaui sumber dayanya, sehingga menuntut upaya yang luar biasa. Hal yang termasuk coping adalah seluruh hal yang dipikirkan atau dilakukan individu dalam upaya beradaptasi terhadap stres, terlepas dari berhasil atau tidaknya hal tersebut. Memilih strategi yang sesuai membutuhkan penilaian yang berkelanjutan terhadap hubungan antara orang dan lingkungannya.

Berdasarkan data di Pengadilan Agama Kota Bekasi, tahun 2012 jumlah perkara cerai sebanyak 1.716, tahun 2013 perkara cerai sebanyak 1.750 dan tahun 2014 menjadi 1.825 perkara cerai (infoperkara.badilag.net diakses tanggal 10 Oktober 2015). Faktor jenis perkara cerai 
terbanyak setiap tahunnya disebabkan ketidak harmonisan $30 \%$, gangguan pihak ketiga $24 \%$, persoalan ekonomi $20 \%$.

Perceraian yang terjadi di Kota Bekasi didominasi oleh ketidak harmonisan dalam rumah tangga selain itu umumnya perceraian diajukan dari pihak istri sebanyak $75 \%$. Perceraian yang terjadi bisa saja disebabkan suaminya tidak bertanggung jawab dalam menafkahi lahir dan batin, bisa juga faktor yang disebabkan eksternal (poskotanews.com diakses pada 03 Februari 2016). Fenomena istri lebih banyak menggugat ini karena ada perasaan ego dan nafsu semata dalam berumah tangga.

Kualitas dalam pernikahan bergantung pada kebahagiaan salah satu pasangan dengan hubungan mereka, sensitivitas mereka satu sama lain, validasi mereka terhadap perasaan satu sama lain, serta keterampilan komunikasi dan manajemen konflik mereka. Menurut Spanier (1976), penyesuaian hubungan suami istri itu merupakan suatu proses yang harus melalui berbagai tahap seperti komunikasi yang efektif, proses menangani konflik-konflik yang terjadi dan kepuasan dalam berbagai hubungan sesama pasangan. Keuletan, kecocokan, dukungan emosional, dan ekspetasi yang berbeda antara laki-laki dan perempuan dapat menjadi faktor- faktor penting.

Penyesuaian tersebut dilakukan apabila kondisi stres seorang istri yang telah menjadi ibu, seperti pengharapan ibu mengenai kualitas perkawinan yang berbeda dengan pasangannya. Selain itu ibu cenderung melakukan suatu tindakan penyesuaian perkawinan dalam memenuhi standar kualitas perkawinan yang dibuatnya.

Bila dalam hal ini ibu memiliki tingkat stres yang tinggi akibat pengaruh stresor yang dialaminya. Seperti yang kita ketahui, bahwa stres sebagai ancaman fisik atau psikologis yang dipersepsikan dengan respon. Hal ini dapat disesuaikan apabila ibu mampu merefleksikan emosiemosi yang ada pada dirinya.

Berdasarkan pembahasan diatas, dapat diketahui bahwa istri cenderung mengedepankan emosi dan amarah dibandingkan suami dalam menyelesaikan permasalahan perkawinan sehingga memutuskan untuk bercerai. Strategi coping yang baik dalam hal ini sangat diperlukan untuk keberlangsungan kualitas perkawinan. Berdasarkan fenomena yang terjadi diatas, penulis tertarik untuk mengetahui bagaimana hubungan antara coping dengan kualitas perkawinan pada ibu rumah tangga.

\section{METODOLOGI}

Penelitian ini dilakukan di wilayah Bekasi. Tempat ini dipilih karena berdasarkan data Badan Peradilan Agama (Badilag) Bekasi merupakan salah satu kota dengan angka perceraian yang tinggi di Indonesia. Waktu penelitian dilakukan terhitung mulai dari bulan Oktober 2015 sampai April 2016.

Populasi ialah semua nilai baik hasil perhitungan maupun pengukuran, baik kuantitatif maupun kualitatif, daripada karakteristik tertentu mengenai sekelompok objek yang lengkap dan jelas (Usman, 2009). Populasi penelitian ini adalah lbu Rumah Tangga yang tidak bekerja serta memiliki suami dan anak berdomisili di wilayah Bekasi.

Sampel adalah bagian dari jumlah dan karakteristik yang dimiliki oleh populasi tersebut (Sugiyono, 2014). Jumlah populasi yang besar dan peneliti tidak mungkin mempelajari semua yang ada pada populasi. Sampel penelitian ini adalah lbu dengan karakteristik sebagai berikut:

1. Sudah menikah

2. Usia 18-40 tahun

3. Tidak bekerja

4. Masih memiliki pasangan (belum berpisah)

5. Usia pernikahan lebih dari 1 tahun

Teknik yang digunakan dalam pengambilan sampel dilakukan dengan probability sampling dengan teknik multistage sampling, sebanyak dua stage (tahap), di antaranya:

1. Menentukan kecamatan di wilayah Bekasi yang akan diteliti sebagai populasi dari ibu dengan teknik simple random sampling. Dikatakan simple karena pengambilan populasi dilakukan 
secara acak tanpa memperhatikan strata. Teknik ini digunakan dalam tahap pertama penentuan wilayah kecamatan yang akan dijadikan tempat penelitian

2. Tahap kedua pengambilan sampel yang diambil dari perwakilan setiap kecamatan yang terpilih dilakukan dengan menggunakan teknik sampling kuota dan incidental sampling sebanyak 20 orang di setiap kecamatan. Didasarkan atas pertimbangan yang sesuai dengan maksud dan tujuan dalam penelitian ini. Teknik ini digunakan untuk menentukan sampel dari populasi yang mempunyai ciri-ciri tertentu sampai jumlah yang diinginkan sebanyak 80 orang.

\section{HASIL DAN PEMBAHASAN}

Berdasarkan penelitian yang telah dilakukan, diketahui nilai koefisien korelasi $\mathrm{rxy}_{x y}$ sebesar 0,351 dan thitung sebesar 3,320 > ttabel sebesar 1,99 sehingga dapat disimpulkan bahwa terdapat hubungan positif antara Coping dengan Kualitas Perkawinan pada lbu rumah tangga di Kota Bekasi. Nilai ini menunjukkan bahwa semakin tinggi Coping maka semakin tinggi Kualitas Perkawinan pada Ibu rumah tangga di Kota Bekasi.

Variabel Coping yang diukur dari dimensi Emotion Focused Coping dan Problem Focused Coping. Berdasarkan hasil perhitungan interpretasi data variabel coping dimensi Emotion Focused Coping lebih sering digunakan oleh lbu Rumah Tangga di Kota Bekasi sebanyak 68\% disbanding Problem Focused Coping yang hanya sebanyak $61 \%$. Hal ini sejalan dengan penelitian yang dilakukan Billings \& Moos (dalam Pramadi \& Lasmono, 2003), dalam menghadapi suatu masalah yang dapat menimbulkan stress wanita memiliki kecenderungan menggunakan Emotion Focused Coping.

Jika dilihat dari perhitungan variabel coping dimensi Emotion Focused Coping, dengan indikator tertinggi indikator memikirkan hal positif. Hal ini berarti lbu rumah tangga di Kota Bekasi ketika dihadapi dengan suatu masalah mencoba untuk memikirkan hal positif. Mayoritas responden Ibu rumah tangga di Kota Bekasi menjawab sangat kuat, menandakan responden berpikir bahwa setiap masalah pasti ada jalan keluar. Memikirkan hal positif merupakan sumber kekuatan karena membantu untuk memikirkan sampai mendapatkan solusinya (Elfiky, 2009).

Indikator terendah mencari akar masalah, menandakan bahwa lbu rumah tangga di Kota Bekasi kurang mampu mencari akar masalah yang di hadapi, hal tersebut dikarenakan berbagai kurangnya pengetahuan responden mengenai langkah awal yang harus diambil dalam mencari akar masalah. Sebab masalah-masalah yang harus dihadapi orang dewasa itu rumit dan memerlukan waktu dan energi untuk di atasi, maka berbagai penyesuaian diri terhadap masalah yang dihadapi (Hurlock, 1980).

Jika dilihat dari perhitungan variabel coping pada dimensi Problem Focused Coping, indikator dengan persentase tertinggi yaitu melakukan pendekatan kepada Tuhan Yang Maha Esa. Hal ini mengartikan Ibu rumah tangga di Kota Bekasi memiliki spritualitas yang baik kepada Tuhan. Mayoritas respoden menjawab sangat kuat dalam hal tersebut. Spritualitas dan keimanan merupakan dimensi yang paling kuat bagi pengalaman manusia. Spritualitas merujuk pada kualitas batin yang dirasakan individu dalam hubungannya dengan Tuhan, makhluk lain dan nurani (Sri Lestari, 2012).

Indikator terendah dari dimensi Problem Focused Coping yaitu melakukan kegiatan fisik meliputi berbagai aktifitas pengalihan dari masalah yang dihadapi. Ibu rumah tangga merasa tidak kuat untuk melakukan kegiatan aktifitas rumah tangga seperti menyapu dan mengepel. Fase keletihan menghadapi masalah ini menyebabkan individu tidak mampu melakukan kegiatan fisik (Sarafino, 2006).

Indikator mengendalikan emosi, indikator ini lebih kepada pengontrolan emosi ketika menghadapi masalah. Emosi cenderung terkait stres, individu sering menggunakan keadaan emosionalnya untuk mengevaluasi stres dan pengalaman emosional (Sarafino, 2006).

Indikator meminta pendapat lingkungan, lingkungan sosial dapat menjadi alternatif bagi individu untuk meminta pendapat atas masalah yang dihadapinya. Meminta pendapat lingkungan 
sosial bisa menjadi dukungan sosial yang diberikan oleh lingkungan masyarakat, orang tua, anggota keluarga lain, saudara dan teman. Dukungan ini meliputi dukungan pemenuhan kebutuhan informasi dan emosional.

Stress merupakan respon terhadap hal-hal yang menimbulkan stressor. Oleh karena itu, lbu Rumah Tangga yang belum mampu mengembangkan keterampilan coping hendaknya berusaha untuk mencari informasi bagaimana merespon stressor dengan cara yang tepat. Selain itu hendaknya lebih bersosialisasi sehingga mendapatkan banyak pembelajaran dari orang lain dan memiliki banyak kesempatan untuk mengembangkan diri (Hardjana, 1994).

Selain itu, Ibu rumah Tangga dapat mempertahankan situasi-situasi yang mendukung mereka dalam melakukan coping. Salah satu yang dapat digunakan memunculkan perilaku memelihara atau menjaga hubungan dan menunjukkan pada pasangan usaha terbaiknya (Reis \& Sprecher, 2009).

Variabel kualitas perkawinan yang diukur dari dimensi kepuasan perkawinan dan kepuasan perkawinan. Berdasarkan hasil interpretasi Variabel Kualitas Perkawinan sebanyak $73 \% \mathrm{lbu}$ Rumah Tangga di Kota Bekasi merasa telah terpenuhinya dimensi Kepuasan Perkawinan dan sebanyak 68\% merasa terpenuhi Penyesuaian Perkawinannya. Jika dilihat pada hasil perhitungan pada variabel Kepuasan Perkawinan, dimensi Kepuasan Perkawinan (Marital Satisfaction) indikator persentase tertinggi yaitu kenyamanan hidup dengan anak. Faktor yang mempengaruhi penyesuaian dengan masa orangtua (parenthood) yang paling penting adalah sikap terhadap perubahan peran yang diperlukan pada masa orangtua dan tempramen anak (Hurlock, 1980). Bila penyesuaian tersebut dijalankan dengan baik maka kepuasan hidup dengan anak pun tercapai.

Indikator yang memiliki persentase terendah pada dimensi Kepuasan Perkawinan (Marital Satisfaction) yaitu memecahkan masalah komunikasi. Komunikasi di antara pasangan suami istri merupakan hal yang penting bagi kelangsungan dan keharmonisan keluarga atau pernikahan (Duvall, 1997).

Indikator kenyamanan hubungan suami istri yang meliputi penyesuaian berbagai aspek dari hubungan suami istri. Penyesuaian hubungan suami istri itu merupakan suatu proses yang harus melalui berbagai tahap seperti proses menangani konflik-konflik yang terjadi dan kepuasan dalam berbagai hubungan sesama pasangan (Spainer, 1976).

Indikator komunikasi efektif, komunikasi efektif ditandai dengan adanya pengertian, dapat menimbulkan kesenangan, mempengaruhi sikap, meningkatkan hubungan sosial yang baik dan pada akhirnya menimbulkan suatu tindakan (Jalaludin, 2008). Selanjutnya, indicator ketidaksepakatan tentang keuangan, hal ini dapat terjadi ketika adanya perbedaan pandangan mengenai penyesuaian pengelolaan keuangan. Uang dan kurangnya uang mempunyai pengaruh yang kuat terhadap penyesuaian diri orang dewasa dengan perkawinannya (Hurlock, 1980).

Pada dimensi penyesuaian perkawinan (Dyadic Adjusment) memiliki persentase tertinggi pada indikator menyesuaikan diri antar pasangan. Hubungan interpersonal memainkan peran yang penting dalam perkawinan yang pentingnya sama dengan hubungan persahabatan dan hubungan bisnis (Hurlock, 1980).

Selanjutnya indikator terendah pada dimensi ini yaitu menyesuaikan waktu santai dan hobi bersama pasangan dalam melakukan penyesuaian perkawinan diperlukannya waktu yang berkualitas untuk mengembalikan keintiman. Bahwa dengan menghabiskan waktu bersama untuk menonton televisi apalagi dimalam hari, hal ini merupakan hiburan favorit mereka yang sudah mempunyai anak (Hurlock, 1980).

Indikator menyesuaikan tugas dan tanggung jawab bahwa salah satu penyesuaian tugas dan tanggung jawab yang diharapkan salah satu paling penting dari suami ialah suami menunjukkan kesungguhannya dalam membiayai pendidikan anak. Masalah tanggung jawab dan peran yang dimiliki oleh pasangan suami istri juga menjadi faktor dalam kepuasan perkawinan. 


\section{KESIMPULAN}

Berdasarkan hasil penelitian yang telah dilakukan oleh peneliti, terdapat hubungan yang positif dan signifikan antara coping dengan kualitas perkawinan pada ibu rumah tangga di Kota Bekasi. Bahwa dalam mencapai Kualitas Perkawinan sangat diperlukan Coping yang baik. Hal ini meliputi kemampuan pemikiran hal positif, melakukan pendekatan kepada Tuhan Yang Maha Esa, kenyamanan hidup dengan anak dan penyesuaian diri antar pasangan.

Penelitian yang telah dilakukan membuktikan bahwa coping yang digunakan dalam membangun kualitas perkawinan di Kota Bekasi menggunakan coping emotion focused coping sebanyak $68 \%$ kemudian problem focused coping sebanyak $61 \%$ menyesuaikan masalah apa yang sedang dihadapinya. Hal ini dikarenakan subyek penelitian menganggap usaha-usaha untuk mengatur emosinya dalam rangka menyesuaikan diri dengan dampak yang akan ditimbulkan oleh suatu kondisi atau situasi penuh tekanan lebih utama dibanding secara aktif mencari penyelesaian dari masalah untuk menghilangkan kondisi atau situasi yang menimbulkan stres.

Pada penelitian ini Kualitas perkawinan yang memiliki rataan capaian cukup tinggi dimana sebanyak $73 \%$ merasa terpenuhi dimensi Kepuasan Perkawinan (Marital Satisfaction) dengan indikator persentase tertinggi yaitu kenyamanan hidup dengan anak dan terendah yaitu memecahkan masalah komunikasi. Pada sebanyak $68 \%$ merasa terpenuhi dimensi Penyesuaian Perkawinan (Dyadic Adjusment) memilki persentase tertinggi pada indikator menyesuaikan diri antar pasangan dan terendah menyesuaikan waktu santai dan hobi bersama pasangan.

\section{IMPLIKASI}

Berdasarkan hasil penelitian, pembahasan dan kesimpulan yang telah dibuat, berikut adalah implikasi mengenai coping dengan kualitas perkawinan pada lbu rumah tangga di Kota Bekasi. Penelitian ini menunjukkan bahwa lbu rumah tangga di Kota Bekasi mempunyai kecenderungan emotion focused coping dalam mencapai kualitas perkawinannya.

$\mathrm{Hal}$ ini memiliki konsekuensi berupa stres yang tinggi bila kurang menyeimbangkan antara Coping yang telah dimilikinya guna mencapai suatu kualitas perkawinan yang diharapkannya. Oleh karena itu dibutuhkan pengelolaan emosi yang baik sesuai peruntukannya, selain itu seringnya meluangkan waktu berdua dan saling mengisi serta saling memahami guna menjaga komitmen pasangan juga di perlukan guna mencapai kualitas perkawinannya.

\section{SARAN}

Berdasarkan hasil penelitian ini, maka disarankan untuk:

1. Bagi lbu Rumah Tangga

Hasil penelitian menunjukkan bahwa rendahnya kemampuan ibu dalam mencari akar masalah serta melakukan kegiatan fisik sehingga hendaknya lbu berusaha mencari informasi bagaimana merespon stressor dengan cara yang tepat. Selain itu hendaknya lbu Rumah Tangga dapat mempertahankan situasi-situasi yang mendukung dalam melakukan coping dalam menjaga keberlangsungan kualitas perkawinan. Cara yang dapat dilakukan adalah dengan memelihara atau menjaga hubungan dan menunjukkan pada pasangan usaha terbaiknya dengan berbagai penyesuaian dengan pasangan, dan menghabiskan waktu dengan pasangan sehingga memiliki banyak kesempatan untuk menambah keintiman dalam mencapai kualitas perkawinan.

2. Penelitian Selanjutnya

Bagi penelitian selanjutnya yang ingin melakukan penelitian mengenai Coping dan kualitas perkawinan, disarankan untuk mencari data-data tambahan yang dapat memberikan 
dukungan dan sumbangan yang berarti seperti melihat kemapuan Coping suami dan tahapan usia perkawinan sehingga dapat dihasilkan data yang lebih lengkap dan terperinci.

\section{DAFTAR PUSTAKA}

[BADILAG] Badan Peradilan Agama. 2014. G rafik Penyebab Perceraian di Peradilan Agama Tahun 2012-2014. infoperkara.badilag.net. Diakses 10 Oktober 2015.

Baron, R A., Byrne, D. 2005. Psikologi sosial .10th ed. Erlangga. Jakarta.

Duvall, E.M..1997. Marriage and Family Development. J.B. Lippincott Company. Philadelphia.

Elfiky, I. 2009. Terapi Berpikir Positif. Zaman. Jakarta.

Hardjana. 1994. Stres Tanpa Distres: Seni Mengolah Stres. Kanisius. Yogyakarta.

Hurlock, E.B. 1997. Psikologi Perkembangan Suatu pendekatan rentang kehidupan. Edisi kelima. Erlangga. Jakarta

Hurlock, Elizabeth B. 1980. Development Psycology A Life-Span Approach. Ed.5.Terjemahan Istiwidayanti. \& Soedjarwo. Erlangga. Jakarta.

Lazarus, R.S., Folkman, S. 1966. Stress, Appraisal, and Coping. Springer Publishing Company. New York.

Lestari, Sri. 2012. Psikologi Keluarga: Penanaman Nilai dan Penanganan Konflik dalam Keluarga E disi Pertama. Kencana Pernada Media Group. Jakarta.

Poskota News. 2013. http://poskotanews.com/2013/12/17/di-bekasi-istri-banyak-gugat- ceraisuami/. Diakses 5 Januari 2016.

Pramadi, A. \& Lamono, H.K. 2003. Koping Stres Pada Etnis Bali, J awa, dan Sunda. Indonesian Psychological J ournal. Anima. Vol. 18, NO. 4, 326-340.

Reis, H.T., Sprecher, S. 2009. Encyclopedia of Human Relationhips Vol. 1 - 3. Sage Publication, Inc. California.

Sarafino, E.P. 2006. Health Psychology: Biopsychosocial Interactions. Fifth Edition. John Wiley\&Sons. USA.

Spanier, G., Cole, C. 1976. Toward a clarification and investigation of marital adjustment. International J ournal of Sociology of the Family. 6, 121-146.

Sugiyono. 2014. Metode Penelitian Pendidikan Pendekatan Kuantitatif, Kualitatif, dan R\&D. Alfabeta. Bandung

Usman, Akbar. 2009. Metode Penelitian Sosial. Bumi Aksara. Jakarta. 